\title{
Mycorrhizal fungi associated with Codonorchis lessonii (Brongn.) Lindl., a terrestrial orchid from Chile
}

\section{Hongos micorrícicos asociados a Codonorchis lessonii (Brongn.) Lindl., una orquídea terrestre de Chile}

\author{
Guillermo Pereira ${ }^{1}$, Laura M. Suz², Verónica Albornoz ${ }^{1}$, Christian Romero ${ }^{3}$, Leonardo García ${ }^{4}$, \\ Victoria Leiva ${ }^{5}$ \& Cristian Atala ${ }^{5 *}$ \\ ${ }^{1}$ Departamento de Ciencias y Tecnología Vegetal, Campus Los Ángeles, Universidad de Concepción, Casilla 234, Los \\ Ángeles, Chile. \\ ${ }^{2}$ Comparative Plant and Fungal Biology. Royal Botanic Gardens Kew, Richmond Surrey, TW9 3DS, UK. \\ ${ }^{3}$ Programa Doctorado en Ciencias Biológicas. Facultad de Ciencias Naturales y Oceanográficas, Universidad de Concepción, \\ Casilla 160-C, Concepción, Chile. \\ ${ }^{4}$ Campo Experimental Valle del Guadiana, Instituto Nacional de Investigaciones Forestales Agrícolas y Pecuarias (INIFAP). \\ Durango, México. Programa Doctorado en Ciencias Forestales, Facultad de Ciencias Forestales. Casilla 154-C, Concepción, \\ Chile. \\ ${ }^{5}$ Instituto de Biología, Facultad de Ciencias, Pontificia Universidad Católica de Valparaíso, Campus Curauma, Avenida \\ Universidad 330, Valparaíso, Chile. \\ *cristian.atala@pucv.cl
}

\begin{abstract}
Almost all orchid species depend on association with fungal partners. These fungal species facilitate orchid seed germination and promote growth and possibly stress tolerance in adult plants, both in the field and laboratory conditions. Codonorchis lessonii is a terrestrial orchid, endemic to southern Chile and Argentina with a currently unknown conservation status. Previous studies have reported Rhizoctonia-like fungi associated with $C$. lessonii in Argentina, but their fungal partners in Chilean populations are unknown. This study aims to characterize and isolate the mycorrhizal fungi associated with adult individuals of $C$. lessonii from three different populations in Central-South Chile. Root sections showing pelotons were used for the isolation and identification of the fungal taxa. Radial fungal growth was measured for all mycelial isolates. The presence of binucleate cells placed all isolates within the families Ceratobasidiaceae and Tulasnellaceae and the identification was confirmed by molecular analysis. Fungal isolates belonging to Ceratobasidiaceae grew at a higher rate than those from Tulasnellaceae. Phylogenetic analyses showed that different fungal partners associate with this orchid, suggesting relatively low specificity. The isolation and identification of the fungal partners of $C$. lessonii could help understand its ecology and contribute in future restoration and propagation initiatives for the species.
\end{abstract}

KeYwords: Ceratobasidium, Ceratorhiza, ITS fungal barcode, orchid fungi, terrestrial orchids, Tulasnellaceae.

\section{RESUMEN}

La mayoría de las especies de orquídeas dependen de la asociación con hongos. Estas especies de hongos facilitan la germinación de las semillas promueven el crecimiento y, posiblemente, la tolerancia al estrés en plantas adultas tanto en terreno como en condiciones de laboratorio. Codonorchis lessonii es una orquídea terrestre, endémica del sur de Chile y Argentina, con un estado de conservación desconocido. Estudios previos han reportado hongos tipo Rhizoctonia asociados con C. lessonii en Argentina, pero los hongos asociados a las poblaciones chilenas no se conocen. Este estudio apunta a caracterizar y aislar los hongos micorrícicos asociados con individuos adultos de $C$. lessonii de tres poblaciones en la zona centro-sur de Chile. Secciones de raíz con evidencia de pelotones se usaron para aislación e identificación de los taxa fúngicos. El crecimiento radial de los hongos se midió en todos los aislados de micelio. La presencia de células binucleadas ubica a todos los aislados dentro de las familias Ceratobasidiaceae y Tulasnellaceae, identificación confirmada con el análisis molecular. Los aislados de las Ceratobasidiaceae crecieron a una tasa mayor que los de las Tulasnellaceae. El análisis filogenético mostró que diferentes hongos se asocian con esta orquídea, sugiriendo una baja especificidad. La identificación y aislamiento de hongos asociados con C. lessonii podría ayudar a entender su ecología y contribuir a futuras iniciativas de propagación y restauración de esta especie.

Palabras clave: Ceratobasidium, Ceratorhiza, código de barras fúngico ITS, hongos orquidioides, orquídeas terrestres, Tulasnellaceae. 


\section{INTRODUCTION}

The Orchidaceae is a cosmopolitan plant family that has its highest diversity in the tropics (Elórtegui \& Novoa, 2008, Heywood et al. 2007). Tropical species are usually epiphytes (Harley \& Smith 1983, Jones 1993, 2006), whereas temperate species are usually terrestrial or rupicolous (Cribb et al. 2003, Dressler 1993, Valadares et al. 2012). In Chile, only terrestrial orchid species are found, distributed in eight genera (Novoa et al. 2015). Most Chilean species are endemic, and they can be found from the northern-most region to the Magallanes Region in the south ranging from $\sim 18^{\circ} \mathrm{S}$ to $55^{\circ} \mathrm{S}$ with a gap in the Atacama Desert (Novoa et al. 2006, 2015). The genus Codonorchis includes two species; C. canisioi Mansf. found in Brazil, and the native C. lessonii (Brongn.) Lindl. (Freuler 2006, Novoa et al. 2015). C. lessonii is distributed only in Chile and Argentina, and is usually found in the understory of temperate forests in the central-southern part of South America (Romero 2012, Novoa et al. 2015). The phytogeographic origin of C. lessonii is still unclear and currently there are no proven theories to explain its presence in Chile where no close relatives are found among other Chilean orchid species (Novoa et al. 2015). This species is related to species of the Orchideae tribe, which include plants that grow mostly in Africa and the Old World (Elórtegui \& Novoa 2008, Novoa et al. 2015, Szlachetko \& Tukallo 2008). For many years it was associated to genera belonging to the Chloraeinae sub-tribe like Chloraea and Bipinnula (Elórtegui \& Novoa, 2008, Freuler 2006, Szlachetko \& Tukallo 2008), however it has been recently placed in the tribe Codonorchideae (Givnish et al. 2015).

Orchids reproduce sexually through seeds that once released depend on mycorrhizal fungi to germinate and sustain early embryo growth (Murguía \& Lee 2007, Pereira et al. 2005a, Smith \& Read 2008). This dependency is due to the lack of developed endosperm in orchid seeds. The fungi supply relevant nutrients to the embryo such as carbon, nitrogen, and phosphorus (Arditti \& Ghani 2000, Smith \& Read 2008). Many orchid species establish a close association with these fungi, sometimes considered parasitic, but the energetic cost of the interaction may be relatively low for the fungal partner (McKendrick et al. 2000). At adult stages, many species maintain symbiotic associations with fungi that colonize the cortical cells of their roots (Pereira et al. 2014, Atala et al. 2015, Herrera et al. 2017). However, the spectrum of fungal partners may change from germination to adult stages of an orchid (Bidartondo \& Read 2008). Most of the fungal partners found associated with autotrophic orchids belong to or show Rhizoctonia traits (Atala et al. 2015, Otero \& Bayman 2009, Mosquera-Espinosa et al. 2010, Pereira et al. 2014, Herrera et al. 2017). However, other Basidiomycetes belonging to Russulaceae and Thelephoraceae, and some Ascomycetes like Tuber spp. have been also found associated with heterotrophic orchids (Dearnaley et al. 2012, Karol et al. 2015, Selosse et al. 2004). Members of the Rhizoctonia complex do not form asexual spores and share certain distinctive vegetative characters (González et al. 2006, Nogueira et al. 2014). The Rhizoctonia complex includes four fungal teleomorphs: Ceratobasidium, Tanatephorus, Tulasnella and Sebacina (Agrios 2002, Goh et al. 1992, Mosquera-Espinosa et al. 2010). Moore (1987) proposed the subdivision of the complex into Ceratorhiza, Epulorhiza and Moniliopsis, based on the number of nuclei per hyphal segment and the ultrastructure of the hyphal septum. Other authors, however, have proposed its division into only two asexual genera, Ceratorhiza (including Ceratobasidium and Thanatephorus) and Epulorhiza (including Tulasnella and Sebacina) (Pereira et al. 2005b, González et al. 2006, Dearnaley et al. 2012). In the last decade, the number of studies on mycorrhizal fungi associated with tropical and terrestrial temperate orchids has increased significantly (Otero \& Bayman, 2009, Otero et al. 2004, 2005, Pereira et al. 2005a, 2005b, Ruibal et al. 2017, Schiebold et al. 2017). However, this is not the case for South American terrestrial orchids, particularly temperate species, where studies are relatively scarce and have focused on a few genera like Bipinnula and Chloraea (Pereira et al. 2014, 2015, 2017, Atala et al. 2015). Recently, Fracchia et al. (2014) isolated a Tullasnella species from Codonorchis lessonii in Argentina and tested it in the symbiotic germination of Gavilea australis. Understanding the fungal association in orchids is of great importance, as fungal availability in the environment may play a key role in orchid distribution and diversity (Brundrett 2007, McCormick et al. 2012, Otero et al. 2002). On the other hand, mycorrhizal fungi can help with the efficient propagation of terrestrial orchids and their re-introduction into natural habitats (Brundrett 2007).

These orchid-fungi associations seem to be specific to some degree, with specificity being the phylogenetic breadth of fungal partners that a plant taxon may be associated with (Otero et al. 2004, Otero \& Bayman 2009, Taylor et al. 2002). One orchid species can associate preferentially with a small range of phylogenetically close fungal partners, while in other cases, with just one particular fungal species or strain. Moreover, specificity can result in increased germination or plant growth when associating with a preferred fungus (Otero \& Bayman 2009). Except for mycoheterotrophs, high specificity in orchid-fungi associations is not common in temperate or boreal areas (Zettler 1997, Zettler \& Hofer 1998, Herrera et al. 2017). In Australia, however, temperate orchid-fungi associations are highly specific, often with one fungal strain associating with only one orchid species (Brundrett 2007, Dixon 1991). There are, nevertheless, other Australian species that associate with a wider diversity of fungi (Brundrett 2007). The degree of specificity may be related to their trophic strategies such as autotrophy or 
mycoheterotrophy, as well as to abiotic conditions (Otero \& Bayman 2009).

To our knowledge, there is no information about the degrees of specificity in the plant-fungal associations of Chilean orchid species (but see Herrera et al. 2017), particularly for $C$. lessonii, which could have a significant impact on their conservation (Ramsay \& Dixon 2003). Reduced distribution or ecological niches of highly specific orchids could be due to a limited distribution or availability of their fungal partners (Leake \& Cameron 2012). Moreover, it has been suggested that a dependence on narrow specific interactions with fungi and pollinators may predispose many orchids to become rare (Dearnaley 2007, Swarts et al. 2010). For in situ conservation and restoration initiatives it is likely that specific fungi must also be reintroduced in order to have successful establishment of adult plants (Ramsay \& Dixon 2003).

The identification and isolation of fungi associated with native and endemic Chilean orchids could help in the conservation and ecological restoration of orchid species, many of which have known conservation problems (Novoa et al. 2015, Atala et al. 2015, 2017,). It may also contribute to the improvement and development of Chilean orchids as ornamental species. The present study aims to isolate, characterize, and identify the fungal species symbiotically associated with adult individuals of Codonorchis lessonii growing in three populations in Central-South Chile.

\section{MATERIALS AND METHODS}

FIELD SAMPLING AND MORPHOLOGICAL IDENTIFICATION OF THE FUNGAL ISOLATES

Individuals of Codonorchis lessonii (Brongn.) Lindl. were collected from three populations in Central-South Chile; 1) Los Guindos sector, road to Antuco Volcano (37 21'31.26" $\mathrm{S}-71^{\circ} 51^{\prime} 33.28^{\prime}$ 'W), 2) Las Chilcas sector, Parque Nacional

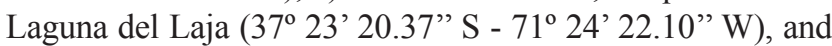
3) Parque Nacional Villarrica ( $37^{\circ} 23^{\prime} 20.37^{\prime \prime} \mathrm{S}-71^{\circ} 24^{\prime}$ 22.10 " W). Populations were located over $35 \mathrm{~km}$ apart from each other. The identification of the species in the field was based on its floral morphology (Freuler 2006, Mourgues 2015, Novoa et al. 2015), very distinctive among Chilean orchids (Novoa et al. 2015, Romero 2012). Three plants per population at least $1 \mathrm{~m}$ away from each other were sampled (a total of 9 individuals). Sampled plants ranged from 15 to $20 \mathrm{~cm}$ tall, considering the flower. For every sampled individual, roots were collected, stored in sealed plastic bags and transported to the laboratory. Roots were rinsed with tap water mixed with Tween 20. Transversal root segments of approximately $2 \mathrm{~mm}$ were cut and sterilized by serial ethanol baths (Otero \& Bayman 2009, Pereira et al. 2014). Roots segments were examined for the presence of pelotons with a dissecting microscope at a $4 \mathrm{X}$ magnification, measuring the $\%$ of the total root section occupied by fungi following previously published methods (Bertolini et al. 2014). Root sections that showed presence of hyphae coils (pelotons) in their cells were placed in Petri dishes with autoclaved potato dextrose agar (PDA) medium at $\mathrm{pH}$ 5.8. The resulting plates were then placed in an oven and incubated in the dark at $24 \pm 1{ }^{\circ} \mathrm{C}$ for 10 days. Growing colonies were observed with a light microscope (Olympus CX30) at 40X and 100X magnification. Hyphal traits such as septum type, branching angle, constrictions of hyphae, and presence of monilioid cells were recorded and photographed using a digital camera attached to a microscope (Moticam 2000). Teleomorph identification was based on the number of nuclei per cell (Agrios 2002, Sneh et al. 1991, Valadares et al. 2012), by measuring 20 young fungal cells per plate. Radial growth was also determined in active fungal colonies isolated from the three orchid populations, averaging the obtained values from four replicates per isolate. Surface-sterilized root segments and mycelial isolates from randomly selected colonies sharing similar characteristics, were chosen from each plant and were individually stored in $300 \mu \mathrm{l}$ of $2 \% \mathrm{CTAB}$ at $-20^{\circ} \mathrm{C}$ until DNA analysis.

MOLECUlAR IDENTIFICATION OF THE FUNGAL ISOLATES

Genomic DNA from individual root sections and from $0.25 \mathrm{~cm}^{2}$ fragments of mycelia collected from the active growing edge of the colonies in PDA medium was extracted following a CTAB protocol (Gardes \& Bruns 1993) using a GeneClean kit (Qbiogene) for DNA purification (Bidartondo et al. 2004). The ITS region of the nuclear ribosomal DNA was amplified using three primer pairs, the eukaryotic one ITS1-ITS4, the fungal specific ITS1F-ITS4, and ITS1-ITS4-tul, specific for the Tulasnellaceae family (Gardes \& Bruns 1993, Taylor \& McCormik 2008, White et al. 1990). PCR products were then purified using ExoSAPit (USB) and bidirectionally sequenced using BigDye 3.1 in an ABI 3730 sequencer (Applied Biosystems).

Sequences were edited using Sequencher v.4.2 (GeneCodes, Ann Arbor, MI) and deposited in GenBank under the accession numbers KT003599 to KT003606 (Table 1). Edited ITS sequences were compared with available sequences in GenBank through BLAST searches (Altschul et al. 1997) to determine their closest known relatives. The top 50 sequences producing the closest hits with each sequence obtained in this study were included in the dataset for phylogenetic analysis. Sequences were aligned and trimmed using the RNA structure-based algorithm Q-INS-i implemented in MAFFT v7.221 (Katoh 2014). Phylogenetic analysis was performed under the maximum likelihood criterion using RAxML (Stamatakis 2014) implemented in raxmlGUI v1.3.1 (Silvestro \& Michalak 2012). The GTRGAMMA model of evolution was used and branch support was assessed using 1000 nonparametric bootstrap replicates. Trees were midpoint rooted. 
DATA ANALYSIS

The software Statistica v.6.0 (StatSoft Inc, OK, USA) was used for statistical analyses. Differences in fungal growth rate (Montgomery 1991) were tested using ANOVA and an a posteriori Tukey test.

\section{RESULTS}

Floral traits confirmed that the sampled individuals corresponded to Codonorchis lessonii in all studied populations (Fig. 1a). Root colonization through root hairs by septate hyphae (Fig. 1b, 1c) and pelotons inside cortical cells in all sampled individuals were observed. Over $85 \%$ of the cell area in the roots was occupied by hyphal coils (Fig. 1d, 1e).

Microscopical observations of the fungal cultures revealed that individuals of the three sampled populations of $C$. lessonii associated with fungi showing Rhizoctonialike traits. The hyphae showed strait angle ramification, simple septa, constriction at the base of a branching hypha, and presence of monilioid cells (Fig. 1g, 1h).

Molecular analyses allowed the identification of the fungal pelotons in the root sections and confirmed the preliminary morphological identifications of the fungal isolates. Based on the GenBank searches, three different fungi belonging to Ceratobasidiaceae (from Antuco and P. N. Villarrica) and one to Tulasnellaceae (P. N. Laguna del Laja) were found (Table 1).

Phylogenetic analyses showed the placement of the sequences with closest matches to Ceratobasidiaceae sequences in three separated, well-supported clades (Fig. 2) and confirmed the identification of the isolates KT003603 and KT003604 as Tulasnellaceae sp. (Fig. 3).

Morphological traits and growth of isolated fungi associated with the roots of $C$. lessonii differed between the orchid populations from which the fungal strains were isolated (Table 2). Isolated strains differed in peloton size within plant cells, hyphae cell size, and monilioid cells size. All isolates showed monilioid cells in pure culture (Fig. 1f, 1h), which also varied in shape and frequency. We observed two nuclei per cell in all isolates (Fig. 1i,). Additionally, isolates identified as Ceratobasidiaceae showed a higher growth rate compared to isolates identified as Tulasnellaceae (Table 2).

\section{DISCUSSION}

We found mycorrhizal fungi associated with the roots of all studied individuals of $C$. lessonii. Intact pelotons were evident in the root cells of all plant populations, occupying over $85 \%$ of the total root section area. This, together with their poor root development (Fig. 1), suggest a close dependence of $C$. lessonii on these mycorrhizal fungi (Novoa et al. 2015). Intact pelotons are a source of inoculum that allows for the re-colonization by hyphae of the outer root surface (Pereira et al. 2005a, 2005b, Sathiyadash et al. 2012) and could be a key strategy for infection of new orchid seedlings in the field. Both, the beneficial mycorrhizal association in terms of plant fitness, and its role as a source of inoculum for new orchid seedlings, could explain the small high-density patches formed by this orchid in the field (personal observation).

Orchids frequently associate with Basidiomycetes belonging to the form-genus Rhizoctonia (Rasmussen 1995, Brundrett 2007, Otero et al. 2013, Pereira et al. 2014, Herrera et al. 2017). These fungi include saprotrophs, ectomycorrhizal fungi, and some parasites and plant pathogens (Dearnaley et al. 2012, Karol et al. 2015). The fungal isolates from all populations of $C$. lessonii showed binucleated young cells and, according to their morphological characteristics, they were preliminarily classified as belonging to Ceratobasidium (Ceratorhiza) and Tulasnella (Epulorhiza). Morphological features are important in classic taxonomy to identify genera and species of fungi. Orchid mycorrhizae have been studied for more than a century (Rasmussen 2002), yet the identification of the fungal species was severely limited until DNA sequencing techniques became more commonly used (McCormick \& Jacquemyn 2014). Molecular techniques are required for greater precision, especially for species within the Rhizoctonia complex (Mosquera-Espinosa et al. 2010, Pereira et al. 2011, Valadares et al. 2012). Both methodological approaches have been used in this study, supporting our conclusions.

Phylogenetic analyses showed that three different fungal strains belonging to Ceratobasidiaceae and one to Tulasnellaceae associate with $C$. lessonii. Fracchia et al. (2014) identified Tulasnella calospora associated with the roots of an Argentinian population of $C$. lessonii. Similar associations with different Ceratobasidium and Tulasnella taxa had also been reported for other endemic Chilean orchids such as Gavilea araucana (Duran et al. 2007), Bipinnula fimbriata (Steinfort et al. 2010), Chloraea collicensis and C. gavilu (Pereira et al. 2014, Herrera et al. 2017), and $C$. cuneata (Atala et al. 2015). Fungi isolated from C. lessonii showed lower growth rates than isolates obtained from roots of other endemic orchids in Chile (Pereira et al. 2014, Steinfort et al. 2010) and the growth rate differed among populations. Further studies of the efficiency of different fungal strains in seed germination and seedling recruitment of this orchid species are needed. 


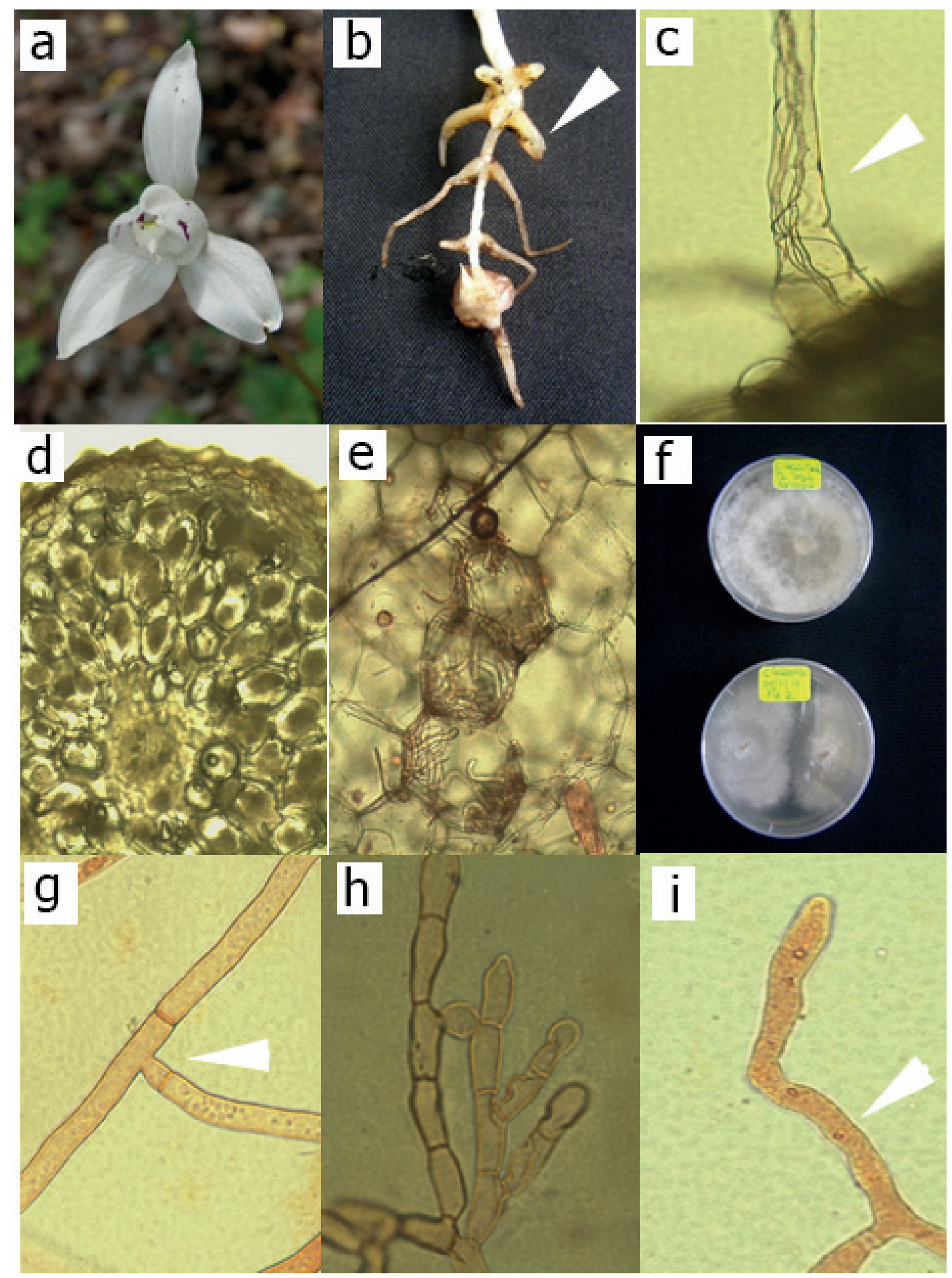

Figure 1. a. Codonorchis lessonii individual. b. Roots of C. lessonii, the arrow indicates areas used for the fungal isolation. c. Hyphae entering the root through a root hair. d. Transversal section of a root showing pelotons inside parenchyma cells. e. Pelotons inside parenchyma cells. f. Isolated fungal colonies. g. Simple septum and $90^{\circ}$ angle hyphal branching of Ceratobasidium. h. Monilioid cells of a Ceratobasidium isolate. i. Binucleated cells of members of Tulasnellaceae. $\mathrm{c}, \mathrm{e}, \mathrm{g}, \mathrm{h}$ and $\mathrm{i}$ taken at 100X magnification. $\mathrm{d}$ taken at $40 \mathrm{X}$ magnification. / a. Individuo de Codonorchis lessonii. b. Raíces de C. lessonii, la flecha indica las áreas utilizadas para el aislamiento fúngico. c. Hifa entrando en la raíz a través de un pelo radical. d. Sección transversal de una raíz mostrando pelotones dentro de las células del parénquima. e. Pelotones dentro de las células del parénquima. f. Colonias fúngicas aisladas. g. El tabique simple y la ramificación de la hifa en ángulo de $90^{\circ}$ de Ceratobasidium. h. Células monilioides de un aislamiento de Ceratobasidium. i. Células binucleadas de miembros de Tulasnellaceae. c, e, g, h e i tomadas a un aumento de 100X. d tomada a un aumento de 40X. 
Gayana Bot. 75(1), 2018

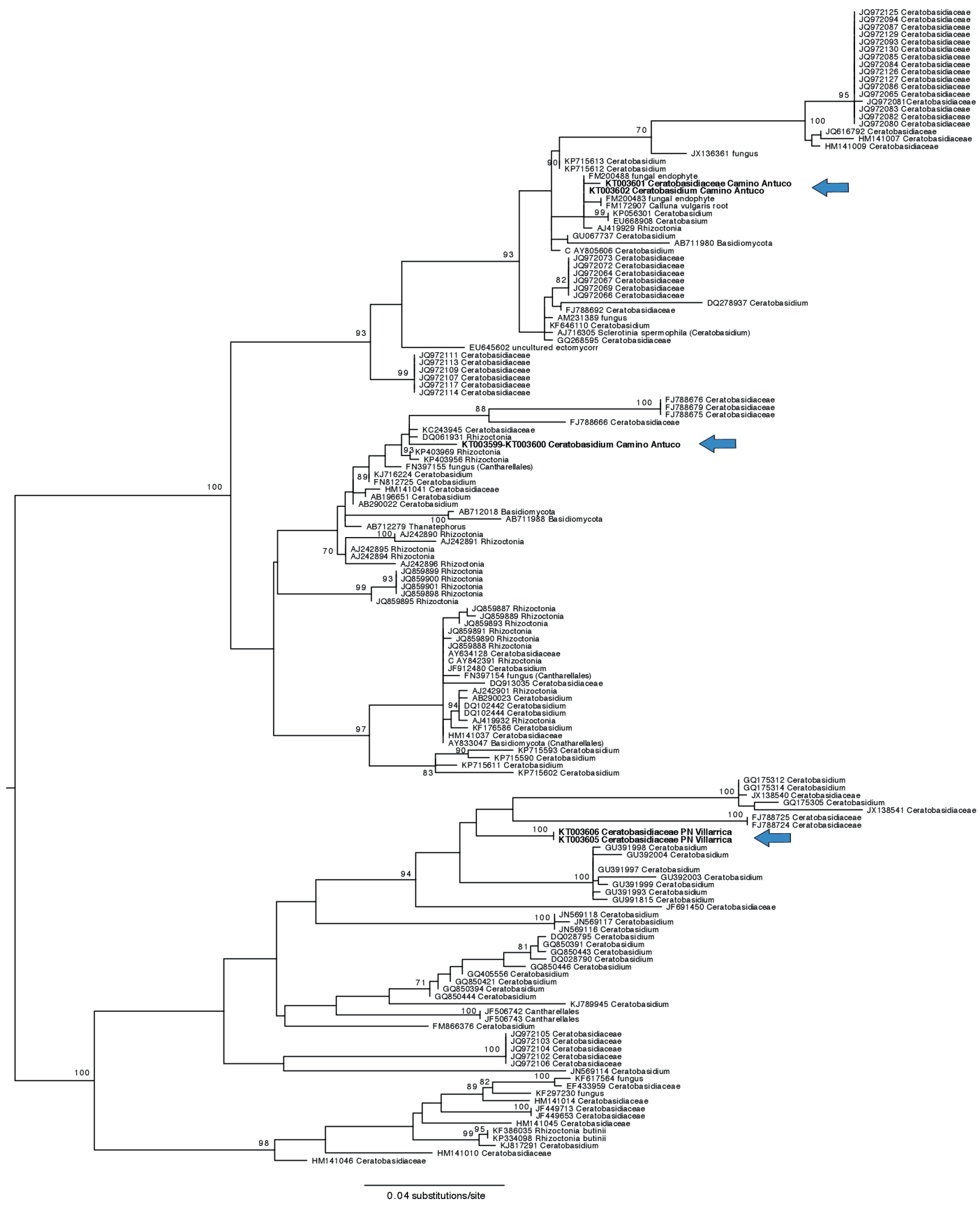

FIGURE 2. Maximum likelihood phylogram showing the phylogenetic placement of the obtained sequences belonging to Ceratobasidiaceae among the most similar sequences retrieved from GenBank as inferred from BLAST searches of the full ITS region. Tree was midpoint rooted. Only bootstrap supports above $70 \%$ are shown. Blue arrows show the placement of the different isolates. / Filograma con máxima verosimilitud que muestra la posición filogenética de las secuencias obtenidas pertenecientes a las Ceratobasidiaceae entre las secuencias más similares obtenidas desde GenBank inferidas de las búsquedas BLAST de la región completa de ITS. El árbol se enraizó en el punto medio. Sólo se muestran soportes de bootstrap por encima del 70 \%. Las flechas azules muestran la ubicación de los diferentes aislamientos. 


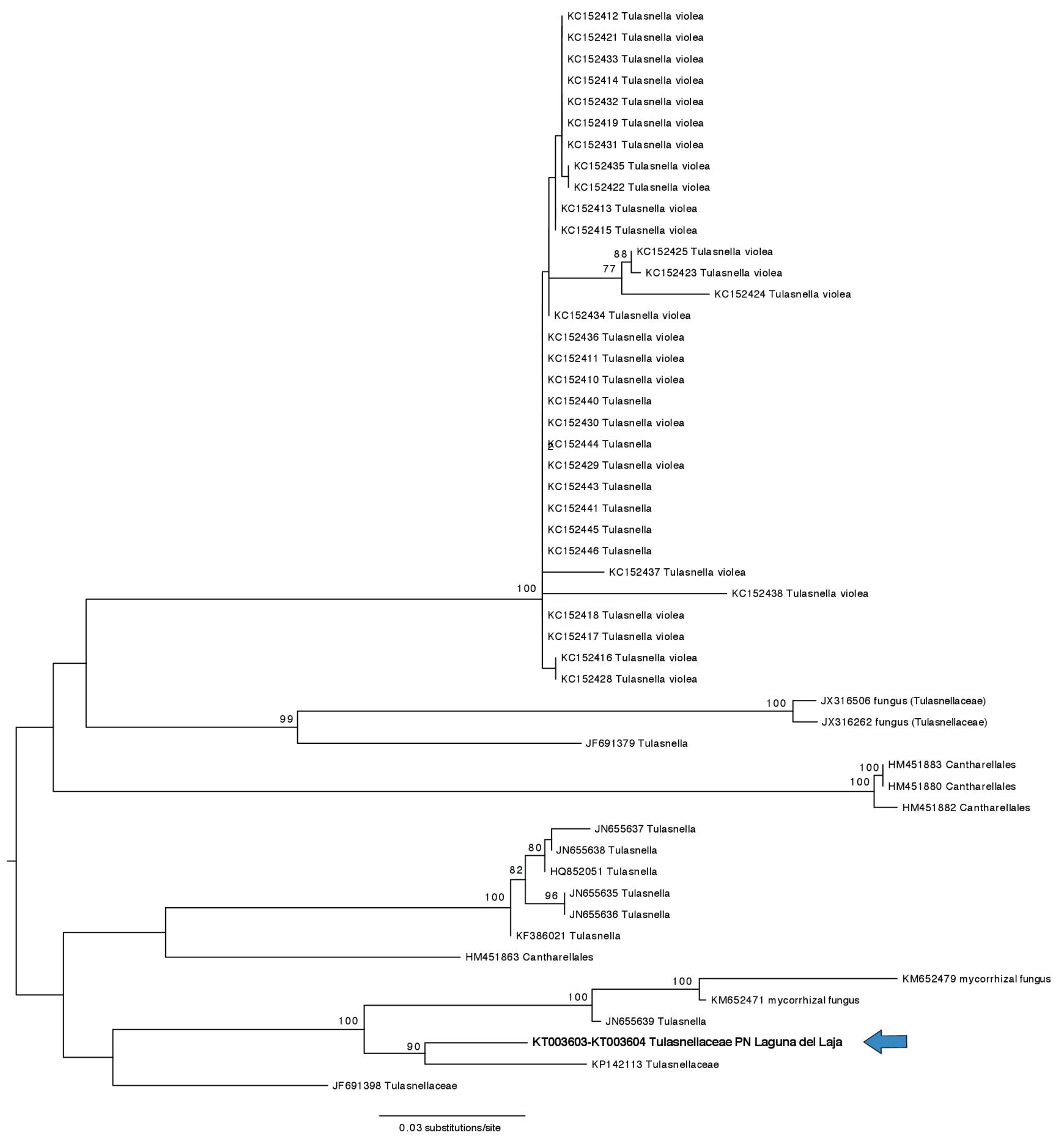

FIGURE 3. Maximum likelihood phylogram showing the phylogenetic placement of the obtained Tulasnellaceae sequences among the most similar sequences retrieved from GenBank as inferred from BLAST searches of the full ITS region. Tree was midpoint rooted. Only bootstrap supports above $70 \%$ are shown. Blue arrows show the placement of the obtained sequences. / Filograma con máxima verosimilitud mostrando la posición filogenética de secuencias de Tulasnellaceae obtenidas entre las secuencias más similares obtenidas desde GenBank inferidas de las búsquedas BLAST de la región completa de ITS. El árbol se enraizó en el punto medio. Sólo se muestran soportes de bootstrap por encima del 70 \%. La flecha azul muestra la ubicación de las secuencias obtenidas de los aislamientos. 
Gayana Bot. 75(1), 2018

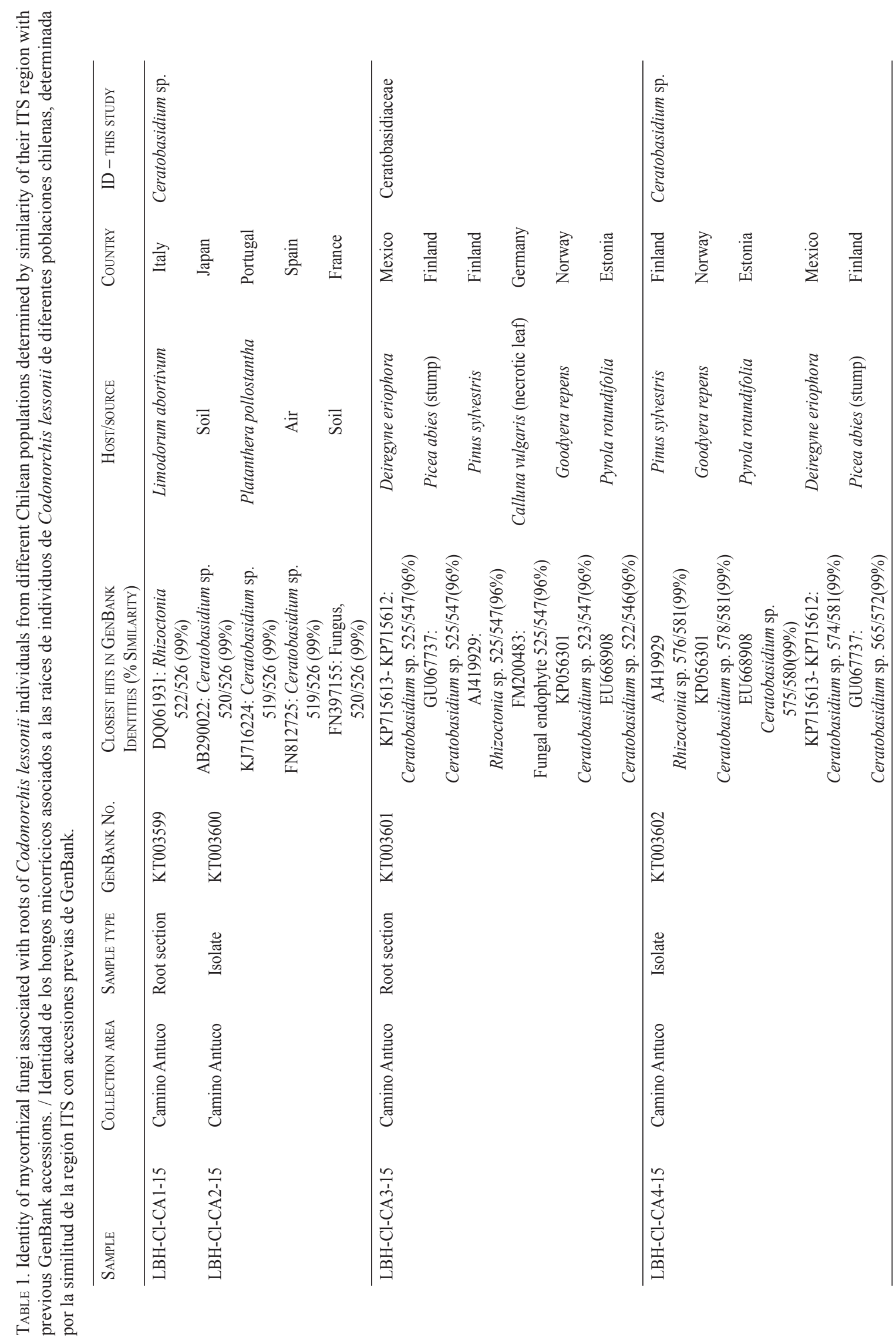



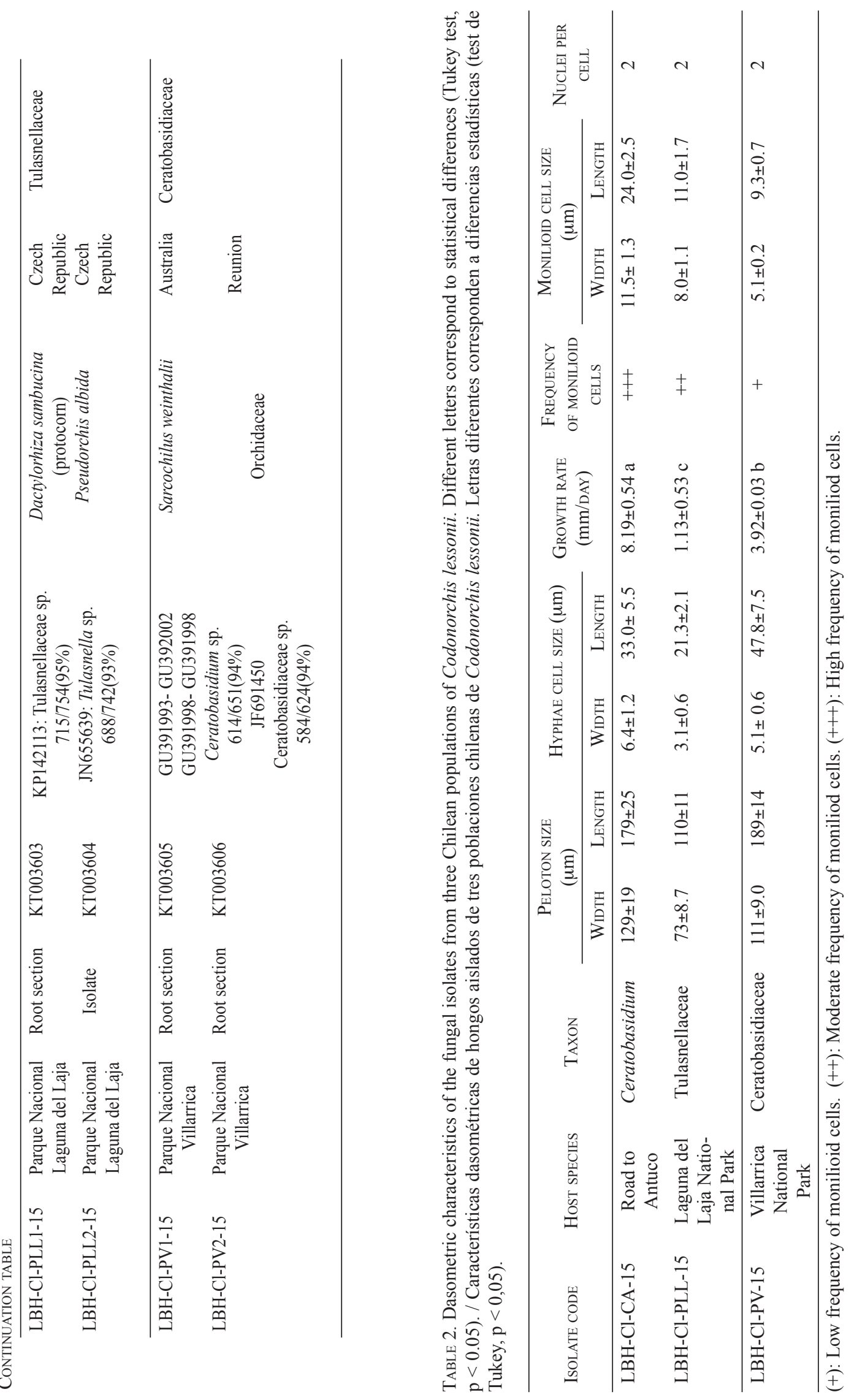
The survival and distribution of an obligate mycorrhizal plant might depend on the distribution of its fungal partners in its habitat (Pandey et al. 2013). The specificity of the fungal-orchid association can vary in different conditions, and laboratory-based experiments do not always reflect the mycorrhizal associations that take place in the wild (PorrasAlfaro \& Hayman 2007, Steinfort et al. 2010). Moreover, different fungi might be required in different stages of the orchid life cycle (Rasmussen 2002). Our results showed that the fungi associated with the roots of $C$. lessonii individuals from different populations are related to other strains found in different hosts and distant geographical areas (Table 1, Fig. 2, 3) more than to each other. Low fungal specificity of $C$. lessonni could explain their abundance in certain areas, since they are not restricted to only one fungal strain to survive and reproduce like some rare orchids that may be limited by specific fungal species availability (Graham \& Dearnaley 2012, McCormick et al. 2012, Swarts et al. 2010). However, it is unknown if specific fungi are required for the natural germination of this species. Recent studies suggest that the distribution of orchids could be limited by the joint effect of suitable habitat availability and pollination limitation (McCormick \& Jacquemyn 2014). Yet another possible factor limiting orchid distributions and acting as a selecting agent could be the orchid-mycorrhizal relationships (Brundrett 2007, Karol et al. 2015, Otero et al. 2004). Further studies with a higher number of individuals per population at different life cycle stages and reciprocal germination and inoculation experiments using different fungal strains are needed to broaden the knowledge about the specificity of these associations. Knowledge of this kind, could help refine laboratory protocols and propagation methods aimed at re-introduction of this orchid species in the field, in future restoration and conservation programs.

Orchid mycorrhizae are excellent models to reveal the general properties of mycorrhizal systems as well as specificity aspects such as ecological networks and evolution of the mycorrhizal status (Dearnaley et al. 2012). In the case of $C$. lessonii, two possibilities arise; 1) if at the adult stage this orchid show low fungal specificity, at least within a certain phylogenetic range, other factors might limit its distribution and abundance; while, 2) if fungal specificity exists at some stage, specific fungi will be required for the laboratory reproduction of individuals from different populations, and the species may be locally restrained by the availability of a suitable fungal partner. This specificity may change during ontogeny but, to our knowledge, no studies have addresses this issue. Further studied are needed to confirm these hypotheses, but our results suggests that C. lessonii associate with phylogenetically distant fungi, at least at the adult stage.

The conservation status of $C$. lessonii is currently unevaluated. This species usually inhabits the understory of forests dominated by Nothofagus species (Freuler 2006, Vidal \& Reif 2011, Vidal et al. 2012) which in their natural state are disappearing due to land use change and anthropogenic activities. This orchid is intolerant to high light exposure and after thinning and clearing of forests, their presence can be severely reduced. Thus, the identification, isolation, and culture of the associated mycorrhizal fungi could be an essential element in their conservation in the long-term and in the understanding of their ecology and evolution.

\section{ACKNOWLEDGMENTS}

The present work was funded by project VRID-UdeC No. 214.418.006-1.0IN and DI-regular 037.446/2015 (PUCV). Authors thank G. Porteous for the English revision of this manuscript and two anonymous reviewers for their useful comments on an earlier version of this manuscript.

\section{REFERENCES}

Agrios, N.G. 2002. Fitopatología. Editorial Limusa, S.A. Segunda edición, México. $635 \mathrm{pp}$

Altschul, S.F., Madden, T.L., SchäFfer, A.A., Zhang, J., Zhang, Z., Miller, W., Lipman, D.J. 1997. Gapped BLAST and PSI-BLAST: a new generation of protein database search programs. Nucleic Acids Research 25: 3389-3402. doi: 10.1093/nar/25.17.3389.

Arditti, J., Ghani, A.K. 2000. Tansley review, 110 - Numerical and physical properties of orchid seeds and their biological implications. New Phytologist 145: 367-421.

Atala, C., Pereira, G., Romero, C., Muñoz-Tapia, L., Vargas, R., Suz, L. M. 2015. Orchidioid fungi of the form-genus Rhizoctonia associated with the roots of Chloraea cuneate Lindl. From Araucanía, Chile. Gayana Botánica 72(1): 145-148.

Atala, C., Muñoz-Tapia L., Pereira, G., Romero, C., Vargas, R., Acuña-Rodríguez, I.S., Molina-Montenegro, M.A., BRITO, E. 2017. The effect of future climate change on the conservation of Chloraea disoides Lindl. (Orchidaceae) in Chile. Brazilian Journal of Botany 40(1): 353-360.

Bertolini, V., Cruz-Blasi, J., Damon, A., Valle Mora, J. 2014. Seasonality and mycorrhizal colonization in three species of epiphytic orchids in southeast Mexico. Acta Botanica Brasilica 28(4): 512-518.

Bidartondo, M.I., Burghardt, B., Gebauer, G., Bruns, T.D., READ, D.J. 2004. Changing partners in the dark: isotopic and molecular evidence of ectomycorrhizal liaisons between forest orchids and trees. Proceedings of the Royal Society of London B Biological Sciences 271: 1799-1806.

BidARTONDO, M.I., READ, D.J. 2008. Fungal specificity bottlenecks during orchid germination and development. Molecular Ecology 17: 3707-3716.

BrundretT, M. 2007. Scientific approaches to Australian temperate terrestrial orchid conservation. Australian Journal of Botany 55: 293-307.

Cribb, P.J., Kell, S.P., Dixon, K.W., Barrett, R.L. 2003. Orchid conservation: a global perspective. In: Dixon, K.W., Kell, S.P., Barrett, R.L., Cribb, P.J. (eds.), Orchid conservation, pp. 113-136. Natural History Publications, Kota Kinabalu, Malaysia.

DeARnAley, J.D. 2007. Further advances in orchid mycorrhizal research. Mycorrhiza 17: 475-486.

Dearnaley, D.W., Martos, F., Selosse, M.A. 2012. Orchid 
mycorrhizas: molecular ecology, physiology, evolution, and conservation aspects. In: Hock, B. (ed.), Fungal associations, pp. 207-230: 2nd edition., Springer-Verlag, Berlin, Germany,

Dixon, K.W. 1991. Seeder/clonal concepts in Western Australian orchids. In: Wells, T.C.E., Willems, J.H. (eds.), Population Ecology of Terrestrial Orchids, pp 111-123. SPB Academic Publishing, The Hague, The Netherlands.

Dressler, R.L. 1993. Phylogeny and classification of the Orchid Family. Cambridge University Press, UK. 314 pp.

Durán, C., Rivero, M., Seemann, P. 2007. Identificación de endomicorrizas en la orquídea nativa Gavilea araucana (Phil.) Correa. Agro Sur 35(2): 6-9.

Elórtegui, S., NovoA, P. 2008. Orquídeas de la Región de Valparaíso. Taller la Era, Viña del Mar, Chile. 83 pp.

Fracchia, S., Aranda-Rickert, A., Flachsland, E., Terada, G., SEDE, S. 2014. Mycorrhizal compatibility and symbiotic reproduction of Gavilea australis, an endangered terrestrial orchid from south Patagonia. Mycorrhiza 24: 627-634.

Freuler, M.J. 2006. Cien orquídeas argentinas. 1era Ed. Editorial Albatro, Buenos Aires, Argentina. 128 pp.

Gardes, M., Bruns, T.D. 1993. ITS primers with enhanced specificity for Basidiomycetes: application to the identification of mycorrhizae and rusts. Molecular Ecology 2: 113-118.

Givnish, T.J., Spalink, D., Ames, M., Lyon, S.P., Hunter, S.J., Zuluaga, A., Iles, W.J.D., Clements, M.A., Arroyo, M.T.K., Leebens-Mack, J., Endara, L., Kriebel, R., Neubig, K.M., Whitten, W.M., Williams, N.H., Cameron, K.M. 2015. Orchid phylogenomics and multiple drivers of their extraordinary diversification. Proceedings of the Royal Society of London B Biological Sciences 282: 20151553. doi: 10.1098/rspb.2015.1553.

GoH, C.J., Sim. A., Lim, G. 1992. Mycorrhizal associations in some tropical orchids. Lindleyana 7: 13-17.

González V., Portal, M.A., Rubio, V. 2006. Review: Biology and Systematics of the form genus Rhizoctonia. Spanish Journal of Agricultural Research 4(1): 55-79.

Graham, R.R., Dearnaley, J.D.W. 2012. The rare Australian epiphytic orchid Sarcochilus weinthalii associates with a single species of Ceratobasidium. Fungal Diversity 54: 31-37.

Harley, J.L., Smith, S.E. 1983. Mycorrhizal symbiosis. Academic Press, London. 483 pp.

Herrera, H., Valadares, R., Contreras, D., Bashan, Y., Arriagada, C. 2017. Mycorrhizal compatibility and symbiotic seed germination of orchids from the Coastal Range and Andes in south central Chile. Mycorrhiza 27: 175-188.

Heywood, V.H., Brummitt, R.K., Culham, A.Y., Seberg, O. 2007. Flowering Plant Families of the World. Firefly Books, Ontario, Canada. 424 pp.

JonEs, D.L. 1993. Native Orchids of Australia. Reed Books, Australia. 656 pp.

JONES, D.L. 2006. A complete guide to native orchids of Australia including the Island Territories. New Holland, Sydney. Australia. 496 pp.

Karol, H., Mosquera-Espinoza, A.T., Otero, J.T. 2015. Propagación in vitro de semillas de la orquídea Comparettia falcata Poepp. \& Endl. (Orchidaceae) mediante técnicas simbióticas y asimbióticas. Acta Agronómica 64(2): 125-
133.

КАтоH, K. 2014. MAFFT v7.221. http://mafft.cbrc.jp/alignment/ software.

LeAKe, J.R., CAmeron, D.D. 2012. Untangling above and below ground mycorrhizal fungal networks in tropical orchids. Molecular Ecology 21: 4921-4924.

McCormick, M.K., JACQuemyn, H. 2014. What constrains the distribution of orchid populations ?. New Phytologist 22: 393-400.

McCormick, M.K., Taylor, D.L., Juhaszova, K., Burnett, R.K., Whigham, D.F., O’Neill, J.P. 2012. Limitations on orchid recruitment: not a simple picture. Molecular Ecology 21: 1511-1523.

McKendrick, S.L., Leake, J.R., Taylor, D.L., Read, D.J. 2000. Symbiotic germination and development of mycoheterotrophic plants in nature: ontogeny of Corallorhiza trifida and characterization of its mycorrhizal fungi. New Phytologist 145: 523-537.

Montgomery, D. 1991. Diseño y análisis de experimentos. Grupo Editorial Iberoamericana, México, DF. 141 pp.

Moore, R.T. 1987. The genera of Rhizoctonia-like fungi: Ascorhizoctonia, Ceratorhiza gen. nov., Eupulorhiza gen. nov., Moniliopsis and Rhizoctonia. Mycotaxon 29: 91-99.

Mosquera-Espinosa, A.T., Bayman, P., Otero, J.T. 2010. Ceratobasidium como hongo micorrízico de orquídeas en Colombia. Acta Agronómica 59(3): 316-326.

Mourgues, V. 2015. Orquídeas de la Región del Maule. Ed. Jardín Botánico. Viña del Mar, Chile. 121 pp.

Murguía, G.J., LeE, E.H. 2007. Manual de producción de orquídeas. Universidad Veracruzana, Xalapa, México. 75 pp.

Nogueira, R.E., Van den Berg, C., Pereira, O.L., Megumi, M.C. 2014. Isolation and molecular characterization of Rhizoctonia-like fungi associated with orchid roots in the Quadrilátero Ferrífero and Zona da Mata regions of the state of Minas Gerais, Brazil. Acta Botánica Brasilica 28(2): 298-300.

Novoa, P., Espejo, J., Cisterna, M., Rubio, M., Domínguez, E. 2006. Guía de campo de las orquídeas chilenas. Ed. Corporación Chilena de la Madera. Concepción, Chile. 239 pp.

Novoa, P., Espejo, J., Alarcón, D., Cisterna, M., Domínguez, E. 2015. Guía de campo de las orquídeas chilenas. Segunda Edición. Ed. Corporación Chilena de la Madera. Concepción, Chile. 244 pp.

Otero, J.T., Ackerman, J.D., Bayman, P. 2002. Diversity and host specificity of endophytic Rhizoctonia-Like fungi from tropical orchids. American Journal of Botany 89(11): 1852-1858.

Otero, J.T., Ackerman, J.D., Bayman, P. 2004. Differences in mycorrhizal preferences between two tropical orchids. Molecular Ecology 13: 2393-2404.

Otero, J.T., Bayman, P. 2009. Germinación simbiótica y asimbiótica en semillas de orquídeas epífitas. Acta Agronomica 58(4): 270-276.

Otero, J.T., Bayman, P., Ackerman, J.D. 2005. Variation in mycorrhizal performance in the epiphytic orchid Tolumnia variegata in vitro: the potential for natural selection. Evolutionary Ecology 19: 29-43.

Otero, J.T., Mosquera, A.T., Flanagan N.S. 2013. Tropical orchid mycorrhizae: potential applications in orchid conservation, commercialization, and beyond. Lankesteriana 13(1-2): 57-63. 
Pandey, M., Sharma, J., Taylor, D.L., Yadon, V.L. 2013. A narrowly endemic photosynthetic orchid is non-specific in its mycorrhizal associations. Molecular Ecology 22: 23412354.

Pereira, O.L., Megumi, M.C., De Lima, C., Montandon, G. 2005a. Isolamento e identificacão de fungos micorrízicos rizoctonióides asociados a três espécies de orquídeas epífitas neotropicais no Brazil. Revista Brasileira do Ciencias do Solo 29: 191-197.

Pereira O.L., Kasuya, C., Borges, A.C., Araujo, E.F. 2005 b. Morphological and molecular characterization of mycorrhizal fungi isolated from neotropical orchids in Brazil. Canadian Journal of Botany 83: 54-65.

Pereira, O.L., Moreira, N., Rogério, M., Megumi, M. 2011. Total fatty acid composition in the characterization and identification of orchid mycorrhizal fungi Epulorhiza spp. Revista Brasileira do Ciencias do Solo 35: 1159-1165.

Pereira, G., Romero, C., Suz, L.M., Atala, C. 2014. Essential mycorrhizal partners of the endemic Chilean orchids Chloraea collicensis and C. gavilu. Flora 209: 95-99.

Pereira, G., Albornoz, V., Muñoz-Tapia, L., Romero, C., Atala, C. 2015. Asymbiotic germination of Bipinnula fimbriata (Orchidaceae) seeds in different culture media. Seed Science and Technology 43: 1-11.

Pereira, G., Albornoz, V., Romero, C., Lara, S., SÁnchez, M., Ríos, D., Atala, C. 2017. Asymbiotic germination of three Chloraea species (Orchidaceae) from Chile. Gayana Botánica 74(1): 131-139.

Porras-Alfaro,A., Bayman, P. 2007. Mycorrhizal fungi of Vanilla: diversity, specificity and effects on seed germination and plant growth. Mycología 99(4): 510-525.

RAmsay, M.M., DixON, K.W. 2003. Propagation science, recovery and translocation of terrestrial orchids. In: Dixon, K.W., Kell, S.P., Barrett, R.L., Cribb, P.J. (eds.), Orchid conservation, pp. 259-288. Natural History Publications, Kota Kinabalu, Malaysia.

Rasmussen, H.N. 1995. Terrestrial Orchids: From Seed to Mycotrophic Plant. Cambridge University Press, Cambridge, UK. 433 pp.

Rasmussen, H.N. 2002. Recent developments in the study of orchid mycorrhiza. Plant and Soil 244: 149-163.

Romero, C. 2012. Orquídeas de Nahuelbuta, Símbolo de la Comuna de Angol. Fondo de Protección Ambiental. Ministerio de Medioambiente, Gobierno de Chile, Chile. 78 pp.

Ruibal, M.P., Triponez, Y., Smith, L.M., Peakall, R., Linde, C.C. 2017. Population structure of an orchid mycorrhizal fungus with genus-wide specificity. Scientific Reports 7: 5613. doi: 10.1038/s41598-017-05855-3.

Sathiyadash, K., Muthukumar, T., Uma, E., Rama-Pandey, R. 2012. Mycorrhizal association and morphology in orchids. Journal of Plant Interactions 7: 238-247.

Schiebold, J., Bidartondo, M.I., Lenhard, F., Makiola, A., GeBauer, G. 2017. Exploiting mycorrhizas in broad daylight: Partial mycoheterotrophy is a common nutritional strategy in meadow orchids. Journal of Ecology 106: 168- 178.

Selosse, M.A., Faccio, A., Scappaticci, G., Bonfante, P. 2004. Chlorophyllous and achlorophyllous specimens of Epipactis microphylla (Neottieae, Orchidaceae) are associated with ectomycorrhizal septomycetes, including truffles. Microbial Ecolology 47: 416-426.

batrmSilvestro, D., Michalak, I. 2012. RaxmlGUI: a graphical frontend for RAxML. Organisms Diversity and Evolution 12: 335-337.

Smith, S.E., Read, D.J. 2008. Mycorrhizal Symbiosis, 3rd ed. Academic Press, San Diego, USA. 815 pp.

Sneh, B., Burpee, L., Ogoshi, A. 1991. Identification of Rhizoctonia species. The American Phytopathological Society, USA. 133 pp.

Stamatakis, A. 2014. RAxML Version 8: A tool for Phylogenetic Analysis and Post-Analysis of Large Phylogenies. Bioinformatics 30: 1312-1313.

SzlachetKo, D.L., Tukallo, P. 2008. Notes on the subtribe Chloraeinae (Orchidaceae). Acta Societatis Botanicorum Poloniae 77: 111-116.

Steinfort, U., Verdugo, G., Besoain, X., Cisterna, M. 2010. Mycorrhizal association and symbiotic germination of the terrestrial orchid Bipinnula fimbriata (Poepp.) Johnst (Orchidaceae). Flora 205: 811-817.

Swarts, N.D., Sinclair, E.A., Francis, A., Dixon, K.W. 2010. Ecological specialization in mycorrhizal symbiosis leads to rarity in an endangered orchid. Molecular Ecology 19: 3226-3242.

Taylor, D.L., Bruns, T.D., Leake, J.R., ReAD, D.J. 2002. Mycorrhizal specificity and function in myco-heterotrophic plants. In: Van der Hejden, M.G.A., Sanders, I.R. (eds.), Mycorrhizal ecology, pp. 375-413. Springer-Verlag, Berlin, Germany.

TAYlor, D.L., McCormick, M.K. 2008. A suite of PCR methods for improved identification of orchid mycorrhizal fungi. New Phytologist 177: 1020-1033.

Valadares, R.B., Pereira, M.C., Otero, J.T., Cardoso, E.J. 2012. Narrow fungal mycorrhizal diversity in a population of the orchid Coppensia doniana. Biotropical 44(1): 114-122.

VIDAL, O.J., REIF, A. 2011. Effect of a tourist-ignited wildfire on Nothofagus pumilio forests at Torres del Paine biosphere reserve, Chile (Southern Patagonia). Bosque 32: 64-76.

Vidal, O.J., San Martín, C., Mardones, S., Bauk, V., Vidal, C. 2012. The orchids of "Torres del Paine" Biosphere Reserve: The need for species monitoring and ecotourism planning for biodiversity conservation. Gayana Botánica 69(1): 136-146.

White, T.J., Bruns, T.D., Lee, S., TAylor, J. 1990. Amplification and direct sequencing of fungal ribosomal RNA genes for phylogenetics. In: Innis, M.A., Gelfand, D.H., Sninsky, J.J., White, T.J. (eds.), PCR Protocols: A Guide to Methods and Applications, pp. 315-322. Academic Press, San Diego, CA, USA.

ZETTLER, L.W. 1997. Terrestrial orchid conservation by symbiotic seed germination: techniques and perspectives. Selbyana 18: $188-194$

Zettler, L.W., Hofer, C.J. 1998. Propagation of the little clubspur orchid (Platanthera clavellata) by symbiotic seed germination, and its ecological implications. Environmental and Experimental Botany 39: 189-195. doi: 10.1016/S0098-8472(97)00019-1. 